\title{
Assessment of microbiological and residual antibiotics status in milk sold in Abeokuta, Ogun State. Nigeria
}

\author{
Flora Oluwafemi ${ }^{1 *}$, Bosede Folashade Oluwabamiwo ${ }^{2}$, Oluseyi Oluwajubelo Oluwatosin ${ }^{1}$, \\ Olufunmilayo Ruth Akinrinade ${ }^{1}$, Adelodun Lawrence Kolapo ${ }^{3}$
}

${ }^{1}$ Department of Microbiology, College of Biosciences, University of Agriculture, PMB 2240, Abeokuta, Nigeria

${ }^{2}$ National Agency for Drug and Food Administration and Control, Oshodi, Lagos. Nigeria

${ }^{3}$ Department of Biological Sciences, Augustine University, Ilara-Epe, Lagos State. Nigeria

\section{A R T I C LE INFO}

\section{Research Article}

Received 12 July 2017

Accepted 01 March 2018

Keywords:

Antibiotics residue

Antibiotics resistance

Microorganisms

Milk

Plasmid

Public health

*Corresponding Author:

E-mail: foluwafemi2000@yahoo.co.uk \begin{abstract}
A B S T R A C T
This study investigated the prevalence and concentration of antibiotic residues in twenty brands of milk. Determination and quantification of antibiotic residues was done using High Performance Liquid Chromatography. Aerobic plate count was carried out and the associated bacteria isolated. Identification of bacteria was done using standard microbiological methods. Molecular characterization and identification of bacterial isolates was done using 16S rRNA gene sequencing method. Antibiotic sensitivity was carried out on bacterial isolates using disc diffusion method. Plasmid profile of drug resistant isolates was done using alkaline analysis method. Comparison of means was done using Analysis of Variance. Antibiotic residues were detected in $10(50 \%)$ of the 20 milk brands analyzed. The residual levels of tetracycline, oxytetracycline and chlortetracycline ranged between $5 \mathrm{ng} / \mathrm{kg}$ and $1569 \mathrm{ng} / \mathrm{kg}$ while none of the samples had doxycycline residues. The prevalence of tetracycline residues in evaporated milk brands and powdered milk samples were 100 and $23 \%$ respectively. The aerobic plate counts ranged from $2.5 \times 10^{2}$ to $6.5 \times 10^{2} \mathrm{CFU} / \mathrm{mL}$ for evaporated milk and $2.5 \times 10^{1}$ to $6.0 \times 10^{1}$ $\mathrm{CFU} / \mathrm{mL}$ for powdered milk. A total of ten bacterial species were isolated and identified. Susceptibility result showed that $95 \%$ of the isolates were sensitive to erythromycin, cefuroxime and gentamycin; $12.5 \%$ were resistant to tetracycline and ampicillin, $10 \%$ were resistant to ofloxacin and $7.5 \%$ to doxycycline and penicillin. Five of the bacterial isolates were resistant to more than one class of antibiotics. Resistant isolates subjected to plasmid profiling had detectable plasmids with estimated sizes between $120 \mathrm{bp}$ and $1000 \mathrm{bp}$. The obtained results provide evidence that the presence of antibiotic residues in evaporated and powdered milk is an indication that the public is exposed to the harmful effects of the residues.
\end{abstract}

DOI: https://doi.org/10.24925/turjaf.v6i6.642-651.1415

\section{Introduction}

Milk and milk products are important sources of animal protein which contribute greatly to human growth and development (Dikko et al., 2010). They contain all the essential food constituents for all age groups and meet the nutritional needs of the body better than any single food (Razzagh et al., 2013). Food for human consumption should be free of all types of compounds of adverse effect to human health. These harmful compounds are not restricted to microorganisms and biological factors and toxins excreted from them, but also all types of chemicals that directly or indirectly contaminate food stuff are equally highly important.

Antibiotics are used extensively in the dairy sector to enhance the health and productivity of animals used for human food. Anti-microbial agents are used in veterinary medicine for therapeutic and prophylactic purposes, maintenance of stable milk supply and as feed additives to enhance growth of farm animals (South Dakota State University, 2015). The major antibiotics used for these animals either belong to the same general classes or have the same mode of action as those used for humans (Joshi, 2002). The extensive use of antibiotics in animals especially dairy cattle result in the presence of trace quantities of the drugs or their metabolites in their products and edible tissues such as milk, meat, muscle, fat and skin (Serratosa et al., 2006; Moreno-Bondi et al, 2009).

The consumption of edible tissues of food of animal origin contaminated with antibiotic residues by humans poses a great risk to public health (Dubois et al., 2001). These kinds of foods contaminated with antibiotics residues have significant effects including: allergies and hypersensitivity reactions (Kassaify et al. 2013), antibiotic resistance (Chauvin et al., 2005), alteration in intestinal microbiota (Bester and Essack, 2010) and carcinogenicity, 
(Moreno-bondi et al., 2009). The major worldwide public concern and health hazard associated with antibiotic residues in animal products is the development of resistant bacterial strains of animal origin and its consequent effect on human health (Aarestrup, 2005). To ensure human food safety, worldwide regulatory authorities such as World Health Organization (1999), and Food and Agriculture Organization (2008), have set maximum residue limits (MRLs) for several veterinary drugs in foods, as well as acceptable daily intake (ADI) of antibiotics by humans (Cinquina et al., 2003; Fritz and Zuo, 2007).

The reality of harmful effects of antibiotic residues in food of animal origin on human health notwithstanding, few studies including Adetunji (2008), Tona and Olusola (2014) investigated on the presence of antibiotic residues in Nigerian milk. Also, the spectrum of antibiotic residues investigated in these studies was only limited to tetracycline, streptomycin and penicillin. The present study therefore investigated the prevalence and concentration of residues of currently and commonly used antibiotics (tetracyline, oxytetracyline, chlortetracycline and doxytetracyline) in twenty brands of evaporated and powdered milks sold in Abeokuta, Nigeria. The microbiological status of these milk samples was also investigated

\section{Materials and Methods}

\section{Sample Collection}

In this study, prepackaged, seven evaporated and 13 powdered milk samples were collected randomly from two local markets in Abeokuta, Ogun State, Nigeria between August and September, 2015. The samples were transported to the laboratory in a cold sterile bag and stored in refrigerator until further analysis.

\section{Reagents and Standards}

All reagents and standards used were of HPLC grade. These include: Acetonitirile $\left(\mathrm{CH}_{3} \mathrm{CN}\right)$, Merck Methanol $\left(\mathrm{CH}_{3} \mathrm{OH}\right)$, Merck, Ammonium acetate, Trifluoroacetic acid and Ammonium hydroxide, and sodium phosphate, Baker. Others are Oxalic acid-dihydrate and EDTAdisodium dihydrate from Merck,Citric acid-monohydrate, Sigma. Chlortetracycline, Tetracycline, Doxycycline and Oxytetracycline standards from US Pharmacopeia, Rockville, MD.

\section{Analysis of Antibiotic Residues}

Antibiotics residues were determined and quantified using High Performance Liquid Chromatography (HPLC) (Hitachi Chromaster 5430 series, equipped with a pump, an ultraviolet detector with an autosampler and a data work station).

\section{Extraction and Quantification of Antibiotic Residues}

Samples of powdered milk were weighed (5 g powdered milk) while for evaporated milk $3 \mathrm{ml}$ was measured into labelled $50 \mathrm{ml}$ polypropylene centrifuge tubes. The powdered milk was dissolved with $10 \mathrm{ml}$ of grade one water and vortex mixed. Twenty millilitre (20 mL) EDTA-McIlvaine buffer $\mathrm{pH} 4.0$ solution was added and vortex-mixed until dissolved.
The mixture was thereafter centrifuged at $4000 \mathrm{rpm}$ for 10 minutes, $1 \mathrm{ml}$ of the supernatant was filtered through an acrodisc syringe filter into HPLC autosampler vials. HPLC autosampler vial and $20 \mu \mathrm{L}$ was then injected into the HPLC. The detector was set $355 \mathrm{~nm}$ and the HPLC chromatograms were recorded on a Chrome master Data Module. The amount of each antibiotic residue in the samples was obtained by comparing the peak height of the sample to that of the standard tetracycline, chlortetracycline, oxytetracycline and doxycycline hydrochlorides.

\section{HPLC Parameters}

Injection volume $(20 \mu \mathrm{l})$, mobile phase (HPLC grade acetonitrile, methanol and water, 15:15:70). Flow rate (0.75 ml/min), Wavelength: $355 \mathrm{~nm}$, Column heater $\left(35^{\circ} \mathrm{C}\right)$, runtime $(15 \mathrm{~min})$. Detection limit for tetracycline: $0.01 \mathrm{ppm}$, Retention time: 4 minutes.

\section{Verification and Repeatability of Measurement}

Measurement traceability: All measuring devices used in the analysis such as balances, pipettes, volumetric flasks, thermometers were calibrated by certified calibrators

Blank milk samples were spiked in triplicates with 25 , 50 and $100 \mathrm{ppb}$ of standard tetracycline, chlortetracycline, oxytetracycline and doxycycline hydrochlorides. The recoveries ranged between $79.037 \%$ for tetracycline, $99.8 \%$, for chlortetracycline, $96.62 \%$ for oxytetracycline and $100.80 \%$ for doxycycline hydrochlorides. Limit of quantitation (LOD and LOQ) were 0.013 and $0.044 \mathrm{ppm}$ for chlortetracycline, oxytetracycline 0.017 and $0.057 \mathrm{ppm}$ for tetracycline and 0.019 and $0.065 \mathrm{ppm}$ for doxycycline hydrochloride. Precision and bias of the method was 0.094 and 1.26 respectively while the expanded uncertainty was 0.342 .

Microbiological analysis of milk samples: A total of 7 evaporated and thirteen powdered milk samples collected from local markets were microbiologically analysed using standard procedures. The samples were tested for the presence of mesophilic, thermophilic bacteria and total aerobic count. In the procedure, for the enumeration of the total aerobic microorganisms, a $1 \mathrm{ml}$ portion of each milk sample was aseptically diluted with $9 \mathrm{ml}$ of sterilized deionized-water. Serial dilutions from $10^{1}$ to $10^{3}$ were prepared. Using the pour plate technique, an aliquot of 0.1 $\mathrm{ml}$ of appropriate dilution was inoculated onto sterile plates and 20mls of prepared Nutrient agar (NA) and deMan Rogosa and Sharpe agar (MRS) $\left(40^{\circ} \mathrm{C}\right)$ were poured into the plates aseptically. Plates were then incubated at $37^{\circ} \mathrm{C}$ for 24 and 48 hours respectively. All colonies on NA and MRS agar were enumerated and recorded in colony forming units per millilitre $(\mathrm{Cfu} / \mathrm{ml})$. For selective plating, each of the milk samples were inoculated on nutrient and MRS agar and were incubated at $37^{\circ} \mathrm{C}$ for 24 and 72 hours respectively. On MRS agar, creamishyellowish colonies were presumptively identified as Lactobacillus and cream large flat colonies on nutrient agar were identified as Bacillus. The suspected colonies were sub-cultured until pure cultures were obtained and were inoculated on nutrient agar slants, incubated at $37^{\circ} \mathrm{C}$ for 24 hours and stored in the refrigerator at $4^{\circ} \mathrm{C}$ for subsequent analysis. 
Characterization of bacterial isolates was done using morphological (size, shape, edge, texture, opacity and colour) and biochemical (Gram's stain, Indole, Methyl red, Voges Proskauer, Citrate utilization, Catalase, Oxidase, Urease, Coagulase and Sugar fermentation) characteristics as described by Barrow and Feltham (2003). Bacterial genomic DNA was extracted from isolates using Qiagen DNA mini kit (250) Cat No 51306. Amplification of fragments of the gene of interest, 16S rRNA gene was carried out with PCR machine as described by Horton and Bruns (2001). The Universal primers used were 27F: AGAGTTTGATCMTGGCTCAG and 1525R: AAGGAGGTGWTCCARCCGCA. Sequencing of the amplified products was performed using ABI PRISM 3700 DNA Analyzer with the Big Dye Terminator v 3.1 Cycle Sequencing Kit. Bi-directional sequences obtained with forward and reverse primers were edited and aligned to generate a consensus sequence using BioEdit sequence Alignment Editor (version 7.1.9). Consensus sequence were then aligned with sequences deposited in the National Centre for bacteriological Information gene bank by using the Basic local Alignment Search Tool (BLAST) to establish identities of the bacteria isolates.

Antimicrobial susceptibility tests: Bacterial isolated from the milk samples were tested for antimicrobial susceptibility using the disc agar diffusion method according to the procedures recommended by the Clinical and Laboratory Standards Institute (CLSI, 2007). Tetracycline, Doxycycline, Ofloxacin, Cefuroxime, Gentamicin, Ampicillin, Penicillin and Erythromycin, the most commonly used antibiotics, were chosen to assess the resistance of the isolated bacteria. Bacterial isolates from the above microbiological analyses were grown on Mueller Hinton agar plates. Tetracycline $(30 \mathrm{mg})$, Doxycycline (15 mg) Ofloxacin, Cefuroxime, Gentamicin, Ampicillin, Penicillin and Erythromycin, (10 mg) antibiotic discs (Abtek Biologicals, UK) and empty discs as control were tested on duplicate plates. The plates were incubated for 24 hours at $37^{\circ} \mathrm{C}$ and the diameter of the zones of inhibition were measured with a metric ruler and interpreted as resistant, intermediate or sensitive according to the CLSI interpretative chart guidelines. Susceptible strains did not grow in the area around the disc; whereas, resistant strains endured the antibiotic(s).

Plasmid profile analysis: The procedure described by Oleghe et al., (2011) was used for plasmid profile analysis. Pure bacterial isolates were inoculated on Mueller- Hinton and was incubated overnight. The grown culture was transferred into $1.5 \mathrm{ml}$ centrifuge tube containing phosphate buffer saline (PBS) and centrifuged at $10000 \mathrm{rpm}$ for 30 seconds. The supernatant was decanted and the pellet cells were suspended in $200 \mu \mathrm{l}$ of solution A (100 mM glucose, $50 \mathrm{mM}$ Tris Hydrochloride (pH 8.0), 10M EDTA) containing $10 \mathrm{mg}$ of lysozyme per $\mathrm{ml}$ and incubated for 30 minutes at $37^{\circ} \mathrm{C}$. The freshly prepared $1 \%$ sodium dodecyl sulphate $(400 \mu \mathrm{l})$ in $0.2 \mathrm{~N}$ $\mathrm{NaOH}$ was added and mixed by inverting tubes. A $30 \%$ potassium acetate solution $(300 \mu \mathrm{l})$ was added, vortex mixed, incubated on ice for 5 minutes and centrifuged at $5000 \mathrm{rpm}$ for 5 minutes. The supernatant was discarded and cells were extracted once with a phenol-chloroform mixture (1:1). Plasmid DNA was precipitated with absolute ethanol and $70 \%$ ethanol and spinned repeatedly thrice. The tubes were opened and allowed to dry in an incubator. Plasmid DNA was dissolved with Trisacetic EDTA buffer (Oleghe et al., 2011) and subjected to agarose gel electrophoresis.

\section{Statistical Analysis}

Data subjected to statistical analysis were analyzed using the software SPSS Version 20. Concentrations of residues were compared by means of 1-way ANOVA (Analysis of variance) at $\mathrm{P}<0.05$.

\section{Results}

The results of antibiotic residues analysis in milk samples are shown in Tables 1 and 2. Ten of 20 (50\%) examined evaporated and powdered milk samples were found to contain tetracycline antibiotic residue. Seven $(100 \%)$ of the evaporated milk brands were positive for oxytetracycline while one $(14.2 \%)$ had traces of tetracycline. None had chlortetracycline and doxycycline residues. Two (15.3\%) of the powdered milk brands screened had traces of oxytetracycline residues while one $(7.69 \%)$ had traces of tetracycline and chlortetracycline residues. None had doxycycline residue. The concentration of antibiotic residues detected in evaporated and powdered milk samples ranged between $5 \mathrm{ng} / \mathrm{L}$ and 1569 ng/L.

The aerobic plate counts ranged from $2.5 \times 10^{2}$ to $6.5 \times 10^{2} \mathrm{CFU} / \mathrm{mL}$ for evaporated milk and $2.5 \times 10^{1}$ $6.0 \times 10^{1} \mathrm{CFU} / \mathrm{mL}$ for powdered milk (Table 3 ). A total of ten bacterial species were isolated and identified as Bacillus subtilis (25\%), Lactobacillus fermentum (20\%), Bacillus mycoides (12.5\%), Lactobacillus plantarum (10\%), Bacillus megaterium (10\%), Lactobacillus acidophilus (10\%) Lactobacillus brevis (5\%), Lactobacillus alimentarius (2.5\%), Lactobacillus delbrueckii (2.5\%) and Micrococcus luteus (2.5\%). However, Bacillus subtilis had the highest frequency of occurrence (25\%) (Figure 1). Susceptibility result showed that $95 \%$ of the isolates were sensitive to erythromycin, cefuroxime, and gentamycin and $12.5 \%$ were resistant to tetracycline and ampicillin, while $10 \%$ were resistant to ofloxacin and $7.5 \%$ to doxycycline and penicillin (Table 4 ).

Table 1 Statistical analyses for levels of tetracycline in positive milk samples

\begin{tabular}{l|cccc}
\hline \multicolumn{1}{c|}{$\begin{array}{c}\text { Type of milk } \\
\text { samples }\end{array}$} & $\begin{array}{c}\text { Sample size } \\
(\mathrm{n})\end{array}$ & $\begin{array}{c}\text { Positive samples } \\
(\mathrm{n})\end{array}$ & $\begin{array}{c}\text { Percentage Positive } \\
\text { samples }(\%)\end{array}$ & $\begin{array}{c}\text { Concentration of positive } \\
\text { samples ng/kg (Mean }+ \text { SE) }\end{array}$ \\
\hline Evaporated & 7 & 7 & 100 & $99.75 \pm 0.13$ \\
Powdered milk & 13 & 3 & 23 & $128.0 \pm 0.09$ \\
Total & 20 & 10 & 50 & $113.87 \pm 0.22$ \\
\hline
\end{tabular}


Table 2 Concentration of antibiotic residues detected in evaporated and powdered milk samples.

\begin{tabular}{|c|c|c|c|c|c|}
\hline $\begin{array}{c}\text { Milk } \\
\text { brands }\end{array}$ & $\begin{array}{c}\text { Tetracycline } \\
(\mathrm{ng} / \mathrm{kg})\end{array}$ & $\begin{array}{c}\text { Oxytetracycline } \\
(\mathrm{ng} / \mathrm{kg})\end{array}$ & $\begin{array}{l}\text { Chlortetracycline } \\
(\mathrm{ng} / \mathrm{ml})\end{array}$ & $\begin{array}{l}\text { Doxycycline } \\
(\mathrm{ng} / \mathrm{ml})\end{array}$ & $\begin{array}{c}\text { Total } \\
\text { residues }\end{array}$ \\
\hline $\mathrm{A}$ & $0.0 \pm 0.0^{\mathrm{a}}$ & $5.0 \pm 0.0^{\mathrm{ab}}$ & $0.0 \pm 0.0^{\mathrm{a}}$ & $0.0 \pm 0.0^{\mathrm{a}}$ & $5.0 \pm 0.0^{\mathrm{ab}}$ \\
\hline $\mathrm{B}$ & $0.0 \pm 0.0^{\mathrm{a}}$ & $97.0 \pm 0.0^{b c}$ & $0.0 \pm 0.0^{\mathrm{a}}$ & $0.0 \pm 0.0^{\mathrm{a}}$ & $97.0 \pm 0.0^{\mathrm{c}}$ \\
\hline $\mathrm{C}$ & $72.00 \pm 0.0^{c}$ & $93.0 \pm 0.0^{\mathrm{bc}}$ & $0.0 \pm 0.0^{\mathrm{a}}$ & $0.0 \pm 0.0^{\mathrm{a}}$ & $93.0 \pm 0.0^{\mathrm{c}}$ \\
\hline $\mathrm{D}$ & $0.0 \pm 0.0^{\mathrm{a}}$ & $90.0 \pm 0.0^{\mathrm{bc}}$ & $0.0 \pm 0.0^{\mathrm{a}}$ & $0.0 \pm 0.0^{\mathrm{a}}$ & $90.0 \pm 0.0^{\mathrm{c}}$ \\
\hline $\mathrm{E}$ & $0.0 \pm 0.0^{\mathrm{a}}$ & $216.0 \pm 0.05^{\mathrm{d}}$ & $0.0 \pm 0.0^{\mathrm{a}}$ & $0.0 \pm 0.0^{\mathrm{a}}$ & $216.0 \pm 0.05^{\mathrm{d}}$ \\
\hline $\mathrm{F}$ & $0.0 \pm 0.0^{\mathrm{a}}$ & $85.0 \pm 0.04^{\mathrm{ab}}$ & $0.0 \pm 0.0^{\mathrm{a}}$ & $0.0 \pm 0.0^{\mathrm{a}}$ & $85.0 \pm 0.04^{\mathrm{b}}$ \\
\hline $\mathrm{G}$ & $0.0 \pm 0.0^{\mathrm{a}}$ & $140.0 \pm 0.04^{\mathrm{c}}$ & $0.0 \pm 0.0^{\mathrm{a}}$ & $0.0 \pm 0.0^{\mathrm{a}}$ & $140.0 \pm 0.04^{\mathrm{c}}$ \\
\hline $\mathrm{H}$ & $0.0 \pm 0.0^{\mathrm{a}}$ & $0.0 \pm 0.0^{\mathrm{a}}$ & $0.0 \pm 0.0^{\mathrm{a}}$ & $0.0 \pm 0.0^{\mathrm{a}}$ & $0.0 \pm 0.0^{\mathrm{a}}$ \\
\hline I & $0.0 \pm 0.0^{\mathrm{a}}$ & $0.0 \pm 0.0^{\mathrm{a}}$ & $0.0 \pm 0.0^{\mathrm{a}}$ & $0.0 \pm 0.0^{\mathrm{a}}$ & $0.0 \pm 0.0^{\mathrm{a}}$ \\
\hline $\mathrm{J}$ & $0.0 \pm 0.0^{\mathrm{a}}$ & $0.0 \pm 0.0^{\mathrm{a}}$ & $0.0 \pm 0.0^{\mathrm{a}}$ & $0.0 \pm 0.0^{\mathrm{a}}$ & $0.0 \pm 0.0^{\mathrm{a}}$ \\
\hline $\mathrm{K}$ & $0.0 \pm 0.0^{\mathrm{a}}$ & $0.0 \pm 0.0^{\mathrm{a}}$ & $0.0 \pm 0.0^{\mathrm{a}}$ & $0.0 \pm 0.0^{\mathrm{a}}$ & $0.0 \pm 0.0^{\mathrm{a}}$ \\
\hline $\mathrm{L}$ & $0.0 \pm 0.0^{\mathrm{a}}$ & $0.0 \pm 0.0^{\mathrm{a}}$ & $0.0 \pm 0.0^{\mathrm{a}}$ & $0.0 \pm 0.0^{\mathrm{a}}$ & $0.0 \pm 0.0^{\mathrm{a}}$ \\
\hline M & $0.0 \pm 0.0^{\mathrm{a}}$ & $0.0 \pm 0.0^{\mathrm{a}}$ & $0.0 \pm 0.0^{\mathrm{a}}$ & $0.0 \pm 0.0^{\mathrm{a}}$ & $0.0 \pm 0.0^{\mathrm{a}}$ \\
\hline $\mathrm{N}$ & $0.0 \pm 0.0^{\mathrm{a}}$ & $0.0 \pm 0.0^{\mathrm{a}}$ & $0.0 \pm 0.0^{\mathrm{a}}$ & $0.0 \pm 0.0^{\mathrm{a}}$ & $0.0 \pm 0.0^{\mathrm{a}}$ \\
\hline $\mathrm{O}$ & $0.0 \pm 0.0^{\mathrm{a}}$ & $29.0 \pm 0.07^{\mathrm{d}}$ & $0.0 \pm 0.0^{\mathrm{a}}$ & $0.0 \pm 0.0^{\mathrm{a}}$ & $29.0 \pm 0.07^{\mathrm{b}}$ \\
\hline $\mathrm{P}$ & $0.0 \pm 0.0^{\mathrm{a}}$ & $0.0 \pm 0.0^{\mathrm{a}}$ & $0.0 \pm 0.0^{\mathrm{a}}$ & $0.0 \pm 0.0^{\mathrm{a}}$ & $0.0 \pm 0.0^{\mathrm{a}}$ \\
\hline Q & $0.0 \pm 0.0^{\mathrm{a}}$ & $153.0 \pm 0.0^{\mathrm{a}}$ & $156.0 \pm 0.02^{\mathrm{b}}$ & $0.0 \pm 0.0^{\mathrm{a}}$ & $309.0 \pm 0.02^{\mathrm{e}}$ \\
\hline $\mathrm{R}$ & $46.00 \pm 0.0^{\mathrm{b}}$ & $0.0 \pm 0.0^{\mathrm{a}}$ & $0.0 \pm 0.0^{\mathrm{a}}$ & $0.0 \pm 0.0^{\mathrm{a}}$ & $46.00 \pm 0.0^{\mathrm{b}}$ \\
\hline $\mathrm{S}$ & $0.0 \pm 0.0^{\mathrm{a}}$ & $0.0 \pm 0.0^{\mathrm{a}}$ & $0.0 \pm 0.0^{\mathrm{a}}$ & $0.0 \pm 0.0^{\mathrm{a}}$ & $0.0 \pm 0.0^{\mathrm{a}}$ \\
\hline $\mathrm{T}$ & $0.0 \pm 0.0^{\mathrm{a}}$ & $0.0 \pm 0.0^{\mathrm{a}}$ & $0.0 \pm 0.0^{\mathrm{a}}$ & $0.0 \pm 0.0^{\mathrm{a}}$ & $0.0 \pm 0.0^{\mathrm{a}}$ \\
\hline
\end{tabular}

Brand A-M are evaporated milk; Brand N-T are powdered milk. Values are means of triplicate readings \pm SE. Mean values with same letter within a column are not significantly different at $\mathrm{P}<0.05$.

Table 3 Total bacteria count of evaporated and powdered milk samples

\begin{tabular}{c|cc}
\hline Milk Brands & Mean (cfu/mL) & Mean + SE \\
\hline A & $5.5 \times 10^{2}$ & $5.57 \pm 1.45^{\mathrm{bc}}$ \\
B & $2.5 \times 10^{2}$ & $2.57 \pm 1.2^{\mathrm{ab}}$ \\
C & $3.0 \times 10^{2}$ & $3.0 \pm 1.15^{\mathrm{ab}}$ \\
D & $4.5 \times 10^{2}$ & $4.57 \pm 1.2^{\mathrm{bc}}$ \\
E & $5.3 \times 10^{2}$ & $5.33 \pm 0.88^{\mathrm{bc}}$ \\
F & $2.5 \times 10^{2}$ & $2.57 \pm 0.88^{\mathrm{ab}}$ \\
G & $6.5 \times 10^{2}$ & $6.57 \pm 2.9^{\mathrm{c}}$ \\
H & $5.5 \times 10^{1}$ & $5.67 \pm 1.2^{\mathrm{a}}$ \\
I & $4.5 \times 10^{1}$ & $4.33 \pm 1.45^{\mathrm{a}}$ \\
J & $5.0 \times 10^{1}$ & $4.67 \pm 1.2^{\mathrm{a}}$ \\
K & $5.5 \times 10^{1}$ & $5.33 \pm 1.2^{\mathrm{a}}$ \\
L & $2.5 \times 10^{1}$ & $2.67 \pm 1.67^{\mathrm{a}}$ \\
M & $5.0 \times 10^{1}$ & $5.33 \pm 1.76^{\mathrm{a}}$ \\
N & $4.5 \times 10^{1}$ & $4.33 \pm 1.2^{\mathrm{a}}$ \\
O & $5.0 \times 10^{1}$ & $6.0 \pm 1.15^{\mathrm{a}}$ \\
P & $6.0 \times 10^{1}$ & $6.0 \pm 1.15^{\mathrm{a}}$ \\
Q & $5.5 \times 10^{1}$ & $5.33 \pm 1.76^{\mathrm{a}}$ \\
R & $6.0 \times 10^{1}$ & $6.0 \pm 1.15^{\mathrm{a}}$ \\
S & $6.0 \times 10^{1}$ & $6.0 \pm 0.58^{\mathrm{a}}$ \\
T & $5.5 \times 10^{1}$ & $5.0 \pm 2.1^{\mathrm{a}}$ \\
\hline
\end{tabular}

Brand A-M are evaporated milk; Brand N-T are powdered milk. Values are means of triplicate, readings \pm SE. Mean, values with same letter within a column are not significantly different at $\mathrm{P}<0.05$.

Table 4 Resistance pattern of the isolates to different antibiotics

\begin{tabular}{l|cc}
\hline \multicolumn{1}{c|}{ Antibiotics } & Resistance $(\%)$ & Sensitivity $(\%)$ \\
\hline Tetracycline & 12.5 & 87.5 \\
Doxycycline & 7.5 & 92.5 \\
Ofloxacin & 10 & 90 \\
Cefuroxime & 5 & 95 \\
Gentamycin & 5 & 95 \\
Ampicillin & 12.5 & 87.5 \\
Penicillin & 7.5 & 92.5 \\
Erythromycin & 5 & 95 \\
\hline
\end{tabular}




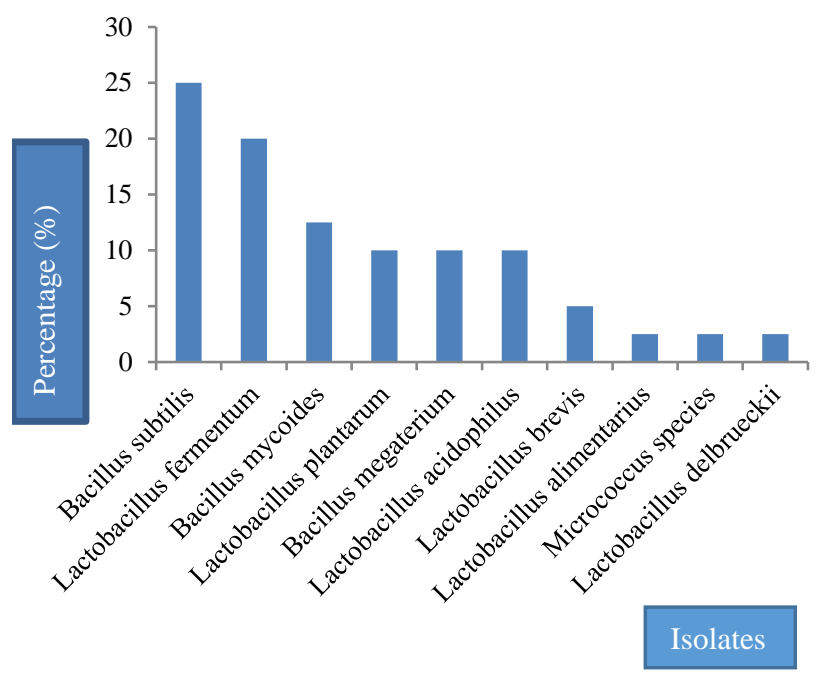

Figure 1 Percentage occurrence of bacterial isolates in evaporated and powdered milk samples

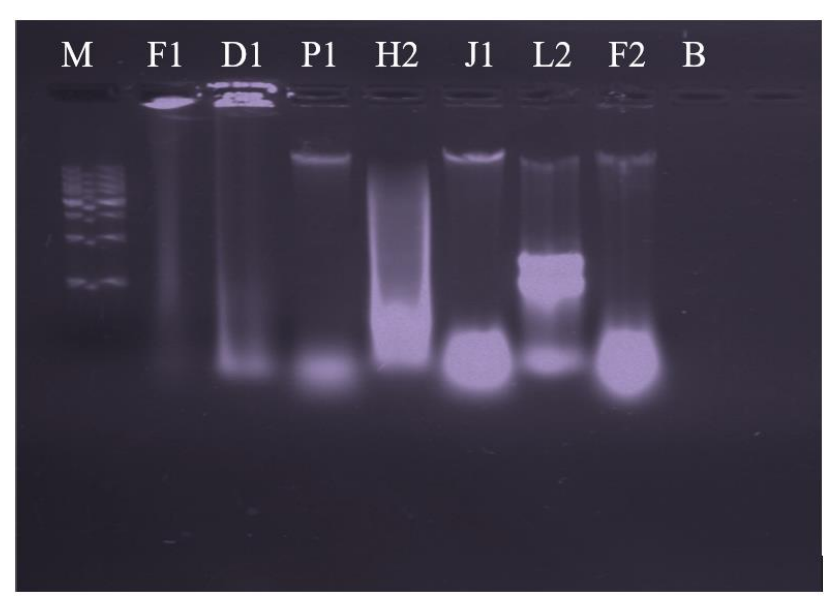

Figure 2 Agarose gel electrophoresis of plasmid DNA isolated from resistant bacteria isolates

F1: Micrococcus luteus (1000bp) D1: Bacillus subtilis (1000bp), P1: Bacillus subtilis (850bp; 120bp), H2: Lactobacillus plantarum (150bp), $\mathrm{J} 1$ : Bacillus subtilis (850bp; 140bp), L2: Lactobacillus delbrueckii (550bp; 140bp), F2: Lactobacillus acidophilus (850bp; 140bp), B = Blank, M= Molecular marker (1000bp ladder)

Table 5 Plasmid weight sizes of the bacterial isolates with visible plasmid bands.

\begin{tabular}{l|lc}
\hline \multicolumn{1}{c|}{ Source } & \multicolumn{1}{c}{ Isolates } & Base pair \\
\hline \multirow{2}{*}{ Evaporated } & Micrococcus luteus & 1000 \\
milk & Bacillus subtilis & 1000 \\
& Lactobacillus acidophilus & 140.850 \\
& Bacillus subtilis & 120.850 \\
Powdered & Lactobacillus plantarum & 150 \\
milk & Bacillus subtilis & 140.850 \\
& Lactobacillus dedelbrueckii & 140.550 \\
\hline
\end{tabular}

Five of the bacterial isolates were resistant to more than one class of antibiotics. Seven drug resistant isolates (Bacillus subtilis, Lactobacillus acidophilus, Lactobacillus plantarum, Lactobacillus delbrueckii and Micrococcus luteus) subjected to plasmid profiling had detectable plasmids with estimated plasmid weight sizes between 120 bp and 1000 bp (Table 5).

\section{Discussion}

Antibiotic residues are commonly found as toxic contaminants which are ingested by humans via foods of animal origin and pose a great risk to public health. It is a major public health concern and a global health hazard (Nisha, 2008). In this study, three different antibiotics (tetracycline, oxytetracycline and chlortetracycline) residues were detected in $10(50 \%)$ out of the total 20 milk brands analysed. The residual levels of the antibiotics screened in this study ranged between $5 \mathrm{ng} / \mathrm{L}$ and $1569 \mathrm{ng} / \mathrm{L}$. The literatures available on the occurrence of antibiotics in milk samples indicate higher rates of antibiotic residues. In Ogbomosho, Nigeria, a study was designed by Tona and Olusola, (2014) to determine the prevalence of tetracycline antibiotics in 40 dairy product samples (cow milk, goat milk, yoghurt, butter fat and soft cheese). All samples (100\%) screened contained residues of tetracycline antibiotics with mean residual levels ranging from 0.0019 to $0.0080 \mathrm{mg} / \mathrm{Kg}$. Soft cheese however, had residues that were significantly higher $(\mathrm{P}<$ 0.05 ) than the other products, though none exceeded the maximum residue limit. Adetunji (2008) reported fiftyeight samples (40 cheese and 18 yoghurt samples) were analyzed for antibiotic residues (streptomycin, penicillin and tetracycline). The mean residual levels ranged between 0.0011 and $0.0062 \mathrm{mg} / \mathrm{Kg}$.

In the United States of America, 10 unexpired cow milk samples were obtained from different suppliers in North Carolina and analysed for the presence of a broad range of antibiotic residues using DelvoP test. Results obtained revealed $9(90 \%)$ out of the 10 examined milk samples had traces of different antibiotic residues at 5 $\mu \mathrm{g} / \mathrm{Kg}$ and higher (Aylin and Erdogan, 2015). In Iran, Mahmoudi et al., (2013) screened 200 raw cow milk samples from dairy farms for the presence of antibiotic residues using Copan milk test, 115 samples (57.70\%) were found to contain antibiotic residues. Also, the results of the evaluation of tetracycline and oxytetracycline residues in milk samples in Tehran province indicated that above $8.7 \%$ of milk samples were positive for antibiotic residues (Rassouli et al., 2010). In Ghana, Aning et al. (2007) reported on the analysis of raw milk samples (394 samples) marketed in two major cities, Accra and Kumasi. Thirty-five percent of the samples were contaminated with one or more of the five families of antibiotics (ßetalactams, tetracycline, aminoglycosides, macrolides and sulphonamides) screened.

In Iran, Mahmoudi et al., (2014) investigated the presence of antibiotic residues in 96 milk samples (18 pasteurized, 24 from milk collection centres and 54 from semi-industrial farms). Based on the results, 28 (29.16\%) of the 96 samples contained antibiotic residues. Moreover, in terms of antibiotic residue contamination, a significant difference was found between raw and pasteurized milk samples $(\mathrm{p}<0.05)$ such that the highest antibiotic contamination $(30.76 \%)$ was found in raw milk samples. In India, the occurrence of tetracycline residues in cattle milk in five districts of Punjab was monitored and analysed. Of the 133 milk samples analysed, 18 samples were found to contain tetracycline residues. The percentages and concentration of tetracycline residues detected from the 5 districts were in the range of 0 - 
$46.15 \%$ and $16-134.5 \mu \mathrm{g} / \mathrm{Kg}$ respectively (Gaurav et al., 2014). The above results showed that there are variations in the level of antimicrobial residues in milk samples consumed in different geographical locations. These differences might be as a result of non-compliance with withdrawal periods by farmers, illegal or off label use of drugs, incorrect dosage and lack of good veterinary practices (Ivona and Mate, 2002; Paturkar et al., 2005). The variations observed could also result from the method of analysis employed by each researcher as each method has its own limitations, also the type of milk examined could also be a contributing factor (Adetunji, 2008). Numerous factors influence the concentration of residues in milk including individual characteristics, health of the animal, amount and type of applied antibiotics, quantity of milk production, method of antibiotic application (Fejzić et al., 2014). The degree of contamination of milk and dairy products with antibiotic residues differs depending on the level of legislation and effectiveness of the methods in different countries (Aalipour et al, 2013).

In this present study, it is noteworthy that none of the tetracycline(s) positive milk brands had tetracycline residues that exceeded the maximum residue limits of 100 $\mu \mathrm{g} / \mathrm{Kg}$ set by World Health Organization (WHO) and Codex Alimentarius. The antibiotic residue concentrations detected ranged from $5 \mathrm{ng} / \mathrm{L}$ to $1569 \mathrm{ng} / \mathrm{L}$. This result is consistent with previous studies in Nigeria by Tona and Olusola, (2014) and Adetunji (2008) in which the highest residue concentration recorded was 0.0080 and 0.0062 $\mathrm{mg} / \mathrm{Kg}$ respectively. In Lebanon, Kassaify et al. (2013) reported the mean residual levels of gentamicin and streptomycin in milk samples to be 90 and $80 \mu \mathrm{g} / \mathrm{Kg}$ respectively. The low concentrations of the tetracycline antibiotics residues observed in this study might be as a result of instability of tetracycline when exposed to heat as recorded by Loksuwan (2002). Moats (1999) observed partial reduction in the occurrence of tetracycline residues concentrations during heat treatment and also found out that temperature at $62^{\circ} \mathrm{C}$ over a period of 30 minutes cause a reduction in chlortetracycline content by $16 \%$ and oxytetracycline by $23 \%$, while $27 \%$ and $35 \%$ reduction were obtained at $72^{\circ} \mathrm{C}$ respectively (Navratilova et al., 2009). The ability of antibiotic residues to cause antibiotic resistance is not as a result of significant doses but sublittle amounts of residues ingested over time build up/ accumulate in the body and often promote the development of resistant strains of bacteria which results in therapeutic failure as a result of the body's sensitivity to them (Adetunji, 2008).

This present study shows that of all the 20 milk brands analysed for tetracycline, oxytetracycline, chlortetracycline and doxycycline residues, oxytetracycline had the highest percentage of $45 \%$, tetracycline had $10 \%$, 5\% for chlortetracycline and none was positive for doxycycline. This result is lower when compared with the report by Navratilova et al., (2009) in Czech Republic where 168 raw cow milk samples were analysed for the presence of antibiotics (tetracycline, chlortetracycline and oxytetracycline) residues. Results showed that all the samples (100\%) analysed contained tetracycline residues ranging between 5 and $24.47 \mu \mathrm{g} / \mathrm{L} .50 .6 \%$ of the samples were positive for oxytetracycline, while none of the samples had chlortetracycline residues nor exceeded the maximum residue limit. Rassouli et al, (2010) reported 37 commercial cow milk samples were screened for oxytetracycline, chlortetracycline and doxycycline antibiotic residues. Results shows oxytetracycline residues were present in all the tested samples (100\%), chlortetracycline in $5(13.5 \%)$ and doxycycline in 2 $(5.40 \%)$ of the samples. The high percentage prevalence of oxytetracycline and tetracycline residues reported in this study might probably be due to the fact that oxytetracycline and tetracycline are the most prescribed antibiotics for animals in veterinary practice (Darwish et al., 2013).

In this study, the antibiotic residue prevalence was higher $(100 \%)$ in evaporated milk brands than powdered milk brands $(23.0 \%)$. This is higher than the results of a study conducted in China in which 94 samples of ultrahigh temperature (UHT) milk and 26 samples of pasteurized milk from China's top dairy brands (I, II, III, IV), were assessed for their contamination with tetracyclines using the ELISA method. It was found that the percentage of UHT milk samples and pasteurized milk samples containing detectable levels of tetracycline were 0 and $7.7 \%$ respectively (Zhang et al., 2014). Literatures report that the exposure of milk to heat processing such as pasteurization does not totally eliminate the presence of residues (Loksuwan, 2002; Navratilova et al., 2009)

Doxycycline antibiotic residue was not detected in all of the 20 milk samples screened in this study. This is in contrast with the findings of Rassouli, (2010) in which 2 of 37 milk samples contained doxycycline residues. The absence of doxycycline antibiotics in the milk brands sampled in this study might be because it is not an approved drug in veterinary medicine and as such less prescribed because of its notable adverse effect of slowing down bone growth (Medicinal Veterinary Animal Health, 2016).

The bacterial loads count from different evaporated (7) and powdered (13) milk brands sampled in this study ranged from $2.57 \pm 0.88$ to $6.57 \pm 2.90$ and $2.67 \pm 1.67$ to $6.0 \pm 1.15 \mathrm{CFU} / \mathrm{mL}$ respectively. This is lower than the report obtained from previous studies. Murugan et al., (2012) reported total viable count from pasteurized milk in India to vary between $4.18 \pm 0.095$ and $4.43 \pm 0.081(\log$ ${ }_{10} \mathrm{CFU} / \mathrm{mL}$ ). Additionally, the lowest viable count of $3.56 \pm 0.078$ was observed in lab-pasteurized milk samples. In Abeokuta, Edema and Akingbade, (2007) reported $0.95 \times 10^{5}-2.15 \times 10^{5} \mathrm{CFU} / \mathrm{mL}$ from unsweetened evaporated milk samples and this is also higher when compared to the counts obtained from this study which ranged from $2.5 \times 10^{2}-6.5 \times 10^{2} \mathrm{CFU} / \mathrm{mL}$ and $2.5 \times 10^{1}$ $6.0 \times 10^{1} \mathrm{CFU} / \mathrm{mL}$ for evaporated and powdered milk respectively. The results obtained in this study are within the satisfactory level for human consumption according to Health Protection Agency (2009). The aerobic plate count satisfactory level for pasteurized foods ranged from $<10^{4}$ $\leq 10^{7}$ while that of powdered milk ranged from $<10^{4}$ $\leq 10^{6}$. However, the difference in values obtained from the studies may be attributed to the milk type/brands and/ or batch used for the analysis, method of analysis and sanitary conditions.

A total of 10 (ten) bacterial species namely: Bacillus subtilis, Lactobacillus fermentum, Bacillus mycoides, Lactobacillus plantarum, Bacillus megaterium, 
Lactobacillus acidophilus, Lactobacillus brevis, Lactobacillus alimentarius, Lactobacillus delbrueckii and Micrococcus luteus were identified from the 20 different commercial milk brands assessed in this study. No milk product was sterile and this shows that pasteurization makes milk safer, it does not render it sterile. This is higher than the results obtained in a similar study carried out in Abeokuta by Edema and Akingbade, (2007) where a total of six bacterial species were isolated from 45 samples of three commonly consumed unsweetened evaporated milk and they are: $B$. cereus, B. licheniformis, B. coagulans, B. stearothermophilus, B. subtilis and $C$. perfringens while Mahami et al., (2011) in Accra, Ghana identified eight bacterial species from eight branded and unbranded milk types (10 fresh pasteurized cow milk (locally-produced), 10 unpasteurized cow milk (locally produced), 10 pasteurized skimmed milk (imported), 10 pasteurized whole milk (imported), 10 soya milk (imported and local), 10 powdered infant milk formula and 10 powdered milk samples) namely E. coli, Klebsiella species, Enterobacter species, P. vulgaris, Salmonella typhi, Enterococcus feacalis, Staphylococcus aureus and S. epidermidis. Murugan et al, (2012) isolated eight Bacillus species from pasteurized milk in India and they are B. subtilis, B. megaterium, B. licheniformis, B. cereus, B.coagulans, B.pumilus, B.sphaericus, and B.circulans. These results shows variations in the types of bacteria species present in commercial milk meant for human consumption. The isolation of different bacterial species in this study could be due to the fact that milk is a nutritive medium and as such capable of enhancing the growth of bacteria contaminants and as well favour the multiplication of starter cultures in the milk samples (USDA, 2015).

Bacillus species were present in $95 \%$ of the brands sampled in this study with $B$. subtilis having the highest occurrence $(25 \%)$. B. subtilis was also the highest occurring bacterial isolates in a study on evaporated milk reported by Edema and Akingbade (2007) and pasteurized milk by Murugan et al., (2012) where they recorded $93.33 \%$ and $33 \%$ respectively. The high occurence of Bacillus species might be due to the fact that they are spore formers and their spores have the ability to survive the temperatures used for pasteurization of the milk samples, which later germinate and multiply (Edema and Akingbade, 2007).

Lactobacillus species were isolated from all brands of milk sampled. This is in contrast to the report by Kateete et al., (2013) that isolated Lactobacillus species from only $9 \%$ of milk samples analysed. The detection of Lactobacillus species in the studied milk products is indicative of its use as starter cultures in the production /fermentation of milk and milk products (Medicinal Veterinary Animal Health, 2016). Micrococcus is a thermoduric bacteria that are generally harmless but can become an opportunistic pathogen in the immunocompromised. The presence of its species in the milk samples screened is indicative of its use in the manufacture of fermented dairy products as reported by the Public Health Agency of Canada (PHAC, 2010).

The antibiogram of the bacterial isolates revealed that only $2.5 \%$ of the isolates were multi drug resistant. This is lower compared to other report on milk and milk products. Guta et al., (2002) reported that most of the 250 Staphylococccal isolates obtained from cow foremilk samples were resistant to one or more of the antimicrobial agents. Multiple resistance patterns were observed in penicillin-ampicillin $(9.3 \%)$ and erythromycin, tetracycline and ampicillin at 3.6\%. Ahmed et al. (2001) and Okpalugo et al. (2008) also reported high antibiotic resistance to tetracycline and other antibiotics by organisms isolated from milk and milk products. In the present study, only one of the isolates (Bacillus subtilis) from brand $\mathbf{J}$ was resistant to three classes of antibiotics namely tetracyclines, aminoglycosides and ßetalactams. In this study $12.5 \%$ resistance to tetracycline and ampicillin was observed. This is lower when compared to $60 \%$ reported by Okonko et al., (2009) to tetracycline and amoxicillin, and $100 \%$ reported by Mahami et al., (2011). Most of the bacterial isolates obtained from the milk samples in this study were susceptible to Cefuroxime, Erythromycin, Gentamycin (95\%) and Penicillin (92.5\%). The effectiveness of Cefuroxime might be attributed to the fact that it is a relatively new antibiotic and has not been extensively used to warrant resistance developing against it by pathogens.

In this study, the presence of traces of oxytetracycline residues in the milk samples did not affect/inhibit the growth of Bacillus mycoides, Bacillus subtilis, Lactobacillus acidophilus, Lactobacillus alimentarius, Lactobacillus fermentum, Lactobacillus plantarum and Microcccus luteus. This might be due to the low concentrations of these residues in the milk samples screened or the resultant chelating effect of the interaction of tetracycline with magnesium and calcium ions or protein casein. As these protein and ions in milk reduces the activity of tetracycline and is capable of rendering it ineffective (Kuang et al., 2009).

Agarose gel electrophoretic analysis in this study revealed the presence of plasmid bands in all the seven bacterial isolates screened. The plasmid bands ranged between $120-1000$ bp (base pair). This is smaller in size compared with the report of previous studies. In Nigeria, Olukoya and Ebigwei (1993) isolated Lactobacillus species from nine locally fermented foods. Of the 50 isolates screened, 40 had plasmids ranging in size from $1.8 \mathrm{~kb}$ to $45.0 \mathrm{~kb}$ and majority of the isolates were reported to carry more than one plasmid. In a study carried out in Pakistan, 116 Lactobacillus species were isolated from fermented milk products and of the total strains investigated for the analysis of plasmid DNA, 22 strains were found positive with large plasmid sizes ranging between 20 and 25kb (Soomro and Masud, 2007). Ombui et al. (2000) isolated various species of Staphylococcus from milk and meats sold in Nairobi and Kiambu districts. Of the 96 isolates ( 75 from milk, 21 from meats) $71 \%$ carried plasmids of molecular sizes ranging between 0.1 to $14.5 \mathrm{~kb}$. These results suggest that each species yielded a different electrophoretic pattern. However, a slight variation among examined strains may be due to different growth conditions used for propagation, difference in the origin of the isolates/ strains, the type of growth media used as well as the variety of the milk sources. Plasmid profiles have been reported to be useful in tracing the epidemiology of antibiotic resistance (Ombui et al., 2000). Plasmids have been known to confer 
resistance to bacterial isolates (Babu et al., 2009). According to Thomas and Summers. (2008), plasmids may be transferred from one bacterium to another via three mechanisms: transformation, transduction and conjugation. The sizes of plasmids varied from 1 to over $200 \mathrm{kbp}$ and plasmids may carry genes that provide resistance to naturally occurring antibiotics in a competitive environmental niche. Finding in this study has been corroborated by Gevers et al. (2003) who reported that Lactobacillus species harbour plasmids of different sizes.

Evaluated milk products clearly poses some yet undefined risks and this is of clinical significance in immunosuppressed people who consume these products as they may eat isolates resistant to some broad spectrum antibiotics. This is because the concentrations of bacteria in milk products vary widely from one manufacturer to another and lack of standardization makes it hard to be sure of the quality. The relatively high level of resistance to antimicrobial agents constitutes a major threat to public health as it may spread bacterial resistance among the populace who come in contact with the milk products. Since public perception of food quality is critical in the marketing of any product, it is very important that the Nigerian milk products industry maintains high processing standards (Okpalugo et al., 2008).

\section{Conclusion}

The antibiotic contamination of food is one of the greatest threat to public health and economic concern that is faced not only by Nigerians but globally. The information presented in this study shows that tetracycline residues are present in milk brands sold in Abeokuta, Nigeria. A considerable percentage of the tested samples contained tetracycline, oxytetracycline and chlortetracycline residues. Although, the concentrations were below the maximum residue limit, accumulation of residues in the body can trigger harmful effect at any point in time. To overcome this global problem of antibiotic residues, it is therefore recommended that regulatory agencies in Nigeria should monitor antibiotic residues in milk meant for human consumption. The use of alternatives to antibiotics, such as plant-derived antimicrobial substances and probiotics may represent a promising option. However, in situations where the use of antibiotics is inevitable, its irrational use in veterinary practices should be avoided.

\section{Acknowledgements}

We acknowledge the selfless support of the immediate-past Director General of NAFDAC, the Head of Lab, Veterinary Drug Residues and all the staffs of the laboratory during the period of the study.

\section{References}

Aalipour F, Mirlohi M, Jalali M. 2013. Prevalence of antibiotic residues in commercial milk and its variation by season and thermal processing methods. Int J Env Health Eng 2:41. DOI: $10.4103 / 2277-9183.122429$;

http://www.ijehe.org/text.asp?2013/2/1/41/122429
Aarestrup FM. 2005.Veterinary drug usage and antimicrobial resistance in bacteria of animal origin. Basic Clinical Pharmacology and Toxicology 96: 271-278. DOI:10.1111/j.1742-7843.2005.pto960401.x PMID: 15755309

Adetunji VO. 2008. Antibiotic residues and drug resistant strains of bacteria in milk products from Ibadan, Southwestern Nigeria. Journal of Tropical Veterinary Medicine 26: 1-6.

Ahmed A, Jamee N, Ansari A, Khatoon H. 2001. Multiple antibiotic resistances among gram negative bacteria isolated from milk in Karachi. Pakistan Journal of Pharamaceutical Sciences. 14: 25-31

Aning KG, Donkor ES, Omore A, Nurah GK, Osafo ELK,. Staal S. 2007. Risk of exposure to marketed milk with antimicrobial drug residues in Ghana. The Open Food Science Journal 1:1-5. http://hdl.handle.net/10568/795

Aylin M, Erdogan M. 2015. Antibiotic residues detected in commercial cow's milk Journal of Emerging Investigators 449(581):147-153.

Babu U, Kesani P,Saddayappan R, Kannalyan K, Yelavarthi IS.2009. Antibiotic sensitivity and plasmid profiles of Escherichia coli isolated from pediatric diarrhea. Journal of Clinical Infectious Diseases 2: 107-110

Barrow GI, Feltham RKA (2003). Cowan and Steel's manual for identification of medical bacteria. Cambridge. . Cambridge University Press.

Bester LA, Essack SY. 2010. Antibiotic resistance via the food chain: Fact or fiction? South African Journal of Science 106:1-5.

Chauvin C, Le Bouquin-Leneveu S, Hardy A, Haguet DO, Sanders JP. 2005. An Original System for the Continuous Monitoring of Antimicrobial Use in Poultry Production in France, Journal of Veterinary Pharmacology and Therapeutics_28(6):515-523.___DOI: 10.1111/j.13652885.2005.00697.x

Clinical and Laboratory Standards Institute. 2007. Performance Standards for Antimicrobial Susceptibility Testing; $16^{\text {th }}$ Information supplement. Clinical and laboratory Standards Institute. Wayne. PA

Cinquina AL Logo F Anastasi G, Gianetti L, Cozzani R. 2003. Validation of a high performance liquid chromatography method for the determination of oxytetracycline, tetracycline, chlortetracycline and doxycycline in bovine milk and muscle. Journal of Chromatography A 987: 227233. PMID: 12613816

Darwish SW, Eldaly AE, El-Abbasy TM, Ikenaka Y, Nakayama S, Ishizuka, M. 2013. Antibiotic residues in food: The African Scenario. Japanese Journal of Veterinary Research 61:13-22.

Dikko AH, Malik AA, Egena SSA, IbrahimH. 2010. Chemical and bacteriological assessment of kindirmo (local yoghurt) put on sale in Niger State. Proceedings of the 35th Annual Conference of the Nigerian Society for Animal Production (NSAP), Nigeria. pp. 794 - 796.

Dubois M, Fluchard D, Sior E, Delahaut PH. 2001. Identification and quantification of five macrolide antibiotics in several tissues, eggs and milk by liquid chromatography-electrospray tandem mass spectrometry, Journal of Chromatography, Biomedical Sciences and Applications 753(2):189-202. PMID:11334331

Edema MO, Akingbade OA. 2007. Incidence of spore forming bacteria in unsweetened evaporated milk brands in Nigeria. Nigerian Food Journal 25:137-144. http://www.bioline.org.br/pdf?nf07013

Fejzić N, Begagić M, Šerić-Haračić S, Smajlović M 2014 Beta lactam antibiotics residues in cow's milk: comparison of efficacy of three screening tests used in Bosnia and Herzegovina. Bosnian Journal of Basic Medical Sciences 14:155. DOI: 10.17305/bjbms.2014.3.109.; PMID:25172975 
Food and Agricultural Organization, 2008. Tolerances for residues of new animal drugs in foods. http://www.accessdata.fda.gov/scripts/cdrh/cfdocs/cfcfr/CF RSearch.cfm?fr=530.41

Fritz JW,. Zuo Y. 2007. Simultaneous determination of tetracycline, oxytetracycline, and 4-epitetracycline in milk by high-performance liquid chromatography. Journal of Food Chemistry 105: 1297-1301. DOI:10.1016/j.foodchem.2007.03.047

Gaurav A, Gill JPS, Aulakh RS, Bedi JS. 2014. Enzyme linked immunosorbent assay based monitoring and analysis of tetracycline residues in cattle milk in various districts of Punjab. Veterinary World 7:26-29. DOI: 10.14202/vetworld.2014.26-29

Gevers D, Danielsen M, Huys G, Swings J. 2003. Molecular characterization of tet $(\mathrm{m})$ genes in Lactobacillus isolates from different types of fermented dairy sausage. Applied Environmental Microbiology 69(2):1270-1275. DOI: 10.1128/AEM.69.2.1270-1275.2003; PMCID: PMC143591

Guta C, Sebunya TK, Gashe BA. 2002. Antimicrobial Susceptibility of Staphylococci species from cow foremilk originating from dairy farms around Gaborone, Botswana. East African Medical Journal 79 (1): 1-4.

Health Protection Agency. 2009. Guidelines for assessing the microbiological safety of ready to eat foods placed on the market, London. Health Protection agency. pp 26

Horton TR, Bruns TD. 2001. The molecular revolution in ectomycorrhizal ecology:Peeking into the black-box. Molecular Ecology 10:1855-1871

Ivona K, Mate D. 2002: Evaluation of the sensitivity of individual test organisms to residual concentrations of selected types of drugs. Slovenian Veterinary Research 9: 78-82.

Joshi S. 2002 High Performance Liquid Chromatogram separation of antibiotics present in formulated and unformulated samples. Journal of Pharmaceutical and Biomedical Analysis 28(5):795-809.

Kassaify Z, Abi Khalil P, Sleiman, F. 2013. Quantification of Antibiotic Residues and Determination of Antimicrobial Resistance Profiles of Microorganisms Isolated from Bovine Milk in Lebanon. Food and Nutrition Sciences 4: 1-9. http://dx.doi.org/10.4236/fns.2013.47A001

Kateete DP Kabugo U, Baluku H, Nyakarahuka L, Kyobe S, Okee M, Naijuka CF, Joloba ML. 2013. Prevalence and antimicrobial susceptibility patterns of bacteria from milkmen and cows with clinical mastitis in and around Kampala, Uganda. PLoS One. 8:e63413. doi: 10.1371/journal.pone.0063413.

Kuang Y, Jia H, Miyanaga K, Yanji Y. 2009. Effect of milk on antibacterial activity of tetracycline against Escherichia coli and Staphylococcus aureus isolated from bovine mastitis. Applied Microbiology and Biotechnology 84(1):135-142. DOI:10.1007/s00253-009-2008-6; PMID:19418049

Loksuwan J. 2002. The effect of heating on multiple residues of tetracyclines in milk. International Journal of Science and Technology 7:17-21.

Mahami T, Odonkor S, Yaro M, Adu-Gyamfi A. 2011. Prevalence of antibiotic resistant bacteria in milk sold in Accra. International Research Journal of Microbiology 2(4):126-132.

Mahmoudi R, Asadpour R, Pajohi-Alamoti MR, Golchin A, Kijani R, Mohammad Pour R, Altafy K. 2013. Raw cowmilk quality: Relationship between antibiotic residues and somatic cell count. International Food Research Journal 20:3347-3350

Mahmoudi R, Amini K, Vahabzade M, Mir H. Vagef R. 2014 Antibiotic residues in raw and pasteurized milk, Iran Journal of Research and Health 4(4): 884-889.
Medicinal Veterinary Animal Health. 2016. Doxycycline antibiotics., Louisiana. Medicinal Veterinary Animal Health pp. 1-2

Moats WA 1999. The effect of processing on veterinary residues in foods. Adv Exp Med Biol. 1999; 459: 233-41; PMID:10335379

Moreno-Bondi MC, Marazuela MD, Herranz S, Rodriguez E. 2009. An overview of sample preparation procedures for LC-MS multiclass antibiotic determination in environmental and food samples. Analytical Bioanalytical Chemistry 395:921-946. DOI:10.1007/s00216-009-2920-8

Murugan B, Rumaresan G, Annal villi R. 2012. Characterization of Bacillus species isolated from pasteurized milk. http://www.tanuvas.tn.nic.in/tnjvas/tnjvas/vol4(1)/13-15.pdf Accessed on 10/07/2017

Navratilova P, Borkovkova I, Drackova M, Janstova B, Vorlova L. 2009. Occurrence of tetracycline, chlortetracycline and oxytetracycline residues in raw cow's milk. Czech Journal of Food Science 27: 379-385.

Nisha AR. 2008. Antibiotics residues: A global health hazard. Veterinary World 1(12): 375-377.

Okonko IO, Soleye FA, Amusan TA, Ogun AA, Ogunnusi TA, Ejembi J. 2009. Incidence of Multi-Drug Resistance (MDR) Organisms in Abeokuta, Southwestern Nigeria. Global Journal of Pharmacology 3(2): 69-80.

Okpalugo OJ, Ibrahim K, Izebe KS, InyangUS. 2008. Aspects of microbial quality of some milk products in Abuja, Nigeria. Tropical Journal of Pharmaceutical Research 7(4):1169-1177.

Oleghe P, Odumegwu D, Udofia E and Esimore C.2011. Multidrug resistant bacteria isolates recovered from herbal medicinal preparations in SouthEastern setting. Nigeria. Journal of Rural and Tropical Public Health 10:70-75

Olukoya DK, Ebigwei SI. 1993. Plasmid profiles and antibiotic susceptibility patterns of Lactobacillus isolated from fermented foods in Nigeria. Journal of Food Microbiology 10:279-285

Ombui JN, Kimotho AM, Nduhiu JG. 2000. Antimicrobial resistance patterns and plasmid profiles of Staphylococcus aureus isolated from milk and meat. East African Medical Journal 77: 463-467

Paturkar AM, Waskar VS, Mokal KV, Zende RJ. 2005. Antimicrobial drug residues in meat and their public health significance-a review. Indian Journal of Animal Sciences 75: 1103-1111.

Public Health Agency of Canada. 2010. Micrococcus. Pathogen data sheet-Infectious substances. http://www.phacaspc.gc.ca/lab-bio/res/psds-ftss/micrococcus-eng.php. Accessed 10/07/2017

Rassouli A, Abdolmaleki Z, Bokaee S, Kamkar A, Shams G. 2010. A cross sectional study on Oxytetracycline and Tetracycline residues in pasteurized milk supplied in Tehran by an HPLC method, International Journal Veterinary Research 4(1): 1-3.

Razzagh M, Kiumars A, Mahtab V, Hamed M, Reza V. 2013. Antibiotic residues in raw and pasteurized milk. Iran Journal of Research and Health 4(4): 884-889

Serratosa J, Blass A, Rigau B, Mongrell B, Rigau T, Tortades M, Tolosa E, Aguilar C, Ribo O, Balague J. 2006. Residues from veterinary medicinal products, growth promoters and performance enhancers in food-producing animals: a European Union perspective. Revue Scientifique et Technique 25: 637-653 PMID:17094703

Soomro AH, Masud T. 2007. Protein pattern and plasmid profile of lactic acid bacteria isolated from Dahi, a traditionally fermented milk product of Pakistan. Journal of Food Technology and Biotechnology 45: 447-453

South Dakota State University. 2015. Beef Procedures: Antibiotic Use in Cattles, Department of Veterinary and Biochemical Sciences, Animal disease research and diagnostic laboratory. pp. 1-4. 
Thomas CM, Summers D. 2008. Bacterial Plasmids. Encyclopedia of Life Sciences. John Wiley and Sons Limited, Chicester. DOI: 10.1002/9780470015902.a0000468.pub2

Tona GO, Olusola AD. 2014. Determination of Tetracycline Antibiotic Residue in Dairy Products Sold in Ogbomoso, South-Western Nigeria International Journal of Food, Agriculture and Veterinary Sciences 4 (1):136-140.

United States Department of Agriculture. 2015. National Nutrient Database for Standard Reference. Agricultural Research Services
World Health Organization.s 1999. Technical Report Series. Evaluation of certain veterinary drug residues in food (Fiftieth report of the Joint FAO/WHO Expert Committee on Food Additives). No. 888.

Zhang YD, Zheng N, Han RW, Zheng BQ,. Yu N,. Li SL, Zheng SS, Wang SQ. 2014. Occurrence of tetracyclines, sulfonamides, sulfamethazine and quinolones in pasteurized milk and UHT milk in China's market Food Control 36: 238-242 